\title{
MODEL DIRECT INSTRUCTION DENGAN TEKNIK PROBING PROMPTING : DAMPAK TERHADAP HASIL BELAJAR FISIKA SISWA KELAS X SMA NEGERI 4 LUBUKLINGGAU TAHUN PELAJARAN 2018/2019
}

\author{
Oleh \\ Nina Trisna ${ }^{1}$, Tri Ariani ${ }^{2}$, Endang Lovisia ${ }^{3}$ \\ Email: Ninatrisna55@gmail.com \\ ${ }^{1}$ Mahasiswa Program Studi Pendidikan Fisika STKIP-PGRI Lubuklinggau \\ ${ }^{2}$ Dosen Program Studi Pendidikan Fisika
}

\begin{abstract}
This study aims to determine the completeness of the learning outcomes of Class X students after applying the Direct Instruction model with Prompting Probing techniques in 4 Lubuklinggau Public High Schools in 2018/2019 Academic Year significantly. This type of research is quasi-experimental research carried out without a comparison class. The design used in this study was one group pre-test post-test. The population in the study was all class X students of SMA Negeri 4 Lubuklinggau, amounting to 143 students. Samples were taken randomly, obtained class X.MIA 2, which amounted to 36 students as samples. Data collection is done by test technique. The collected data was analyzed using the t-test at a significant level $\alpha$ $=0.05$. Based on the results of data analysis, it can be concluded that the results of physics learning in class X of SMA Negeri 4 Lubuklinggau after the Probing Prompting technique were applied were significantly completed. The average score of students' final test is 75.11 and the percentage of students who complete is $80.5 \%$.
\end{abstract}

Abstrak : Penelitian ini bertujuan untuk mengetahui ketuntasan hasil belajar siswa Kelas X setelah diterapkan model Direct Instruction dengan teknik Probing Prompting di SMA Negeri 4 Lubuklinggau Tahun Pelajaran 2018/2019 secara signifikan tuntas. Jenis penelitian ini adalah penelitian eksperimen semu yang dilaksanakan tanpa ada kelas pembanding. Desain yang digunakan dalam penelitian ini adalah one group pre-test post-test. Populasi dalam penelitian seluruh siswa kelas X SMA Negeri 4 Lubuklinggau yang berjumlah 143 siswa. Sampel diambil secara acak, didapatkan kelas X.MIA 2 yang berjumlah 36 siswa sebagai sampel. Pengumpulan data dilakukan dengan teknik tes. Data yang terkumpul dianalisis menggunakan uji-t pada taraf signifikan $\alpha=0,05$. Berdasarkan hasil analisis data dapat disimpulkan bahwa hasil belajar fisika siswa kelas X SMA Negeri 4 Lubuklinggau setelah diterapkan teknik Probing Prompting secara signifikan tuntas. Rata-rata nilai tes akhir siswa sebesar 75,11 dan presentase jumlah siswa yang tuntas sebesar $80,5 \%$.

(C) 2019 Physics Education Department, STKIP PGRI Lubuklinggau, Indonesia

Kata kunci $\quad$ : Direct Instruction, Probing Prompting, Hasil Belajar, Fisika

\section{PENDAHULUAN}

Belajar adalah suatu aktivitas atau suatu proses untuk memperoleh pengetahuan, meningkatkan keterampilan, memperbaiki perilaku, sikap dan mengokohkan kepribadian. dalam konteks menjadi tahu atau proses memperoleh pengetahuan, menurut pemahaman sains konvensional, kontak manusia dengan alam diistilahkan dengan pengalaman (dalam Suyono dan Hariyanto, 2012:9). Belajar juga merupakan suatu aktivitas yang dilakukan tiap individu untuk 
mendapatkan perubahan dalam dirinya melalui pengalaman.

Dalam proses pembelajaran disekolah tugas utama seorang guru ialah mengajar sedangkan tugas siswa ialah belajar (dalam Hardini dan Puspitasari, 2012:5) tujuan belajar adalah untuk mendapatkan pengetahuan, penanaman konsep dan keterampilan, dan pembentukan sikap. Proses pembelajaran ini terjadi secara internal yang sifatnya didalam diri setiap individu agar proses pembelajaran tersebut mengarah pada tercapainya tujuan pembelajaran maka dari itu seorang guru atau pengajar hendaknya merancang dengan baik dari berbagai pengalaman belajar yang bisa menciptakan perubahan tingkah laku setiap individu sesuai dengan apa yang diinginkan.Kegiatan belajar mengajar juga terjadi karena adanya interaksi antar guru dan siswa dengan begitu proses pembelajaran akan terlaksana sesuai dengan tujuan yang diinginkan. Didalam belajar juga semua fasilitas harus memungkinkan sehingga siswa semangat untuk belajar. Pada saat melaksanakan pembelajaran ada beberapa hal yang harus diperhatikan oleh seorang guru yaitu tahapan mengajar, penggunaan model atau pendekatan dan penggunaan prinsip mengajar. Secara umum ada tiga pokok dalam strategi mengajar, yakni tahap permulaan, tahap pengajaran, dan tahap penilaian/tidak lanjut. Ketiga tahapan ini harus ditempuh pada setiap saat melaksanakan pengajaran, jika satu tahapan tersebut ditinggalkan, maka sebenarnya tidak dapat dikatakan telah terjadi proses pengajaran atau dapat dikatakan satu rangkaian kegiatan yang terpadu dan tidak dapat dipisahkan satu sama lain (dalam Hardini dan Puspitasari, 2012:51). Selain itu guru harus membuat suasana kelas atau lingkungan menjadi nyaman dan menarik dengan menggunakan model pembelajaran yang sesuai dengan materi yang akan disampaikan sehingga pembelajaranpun benar-benar searah dengan perkembangan siswa.

Berdasarkan hasil wawancara kepada guru mata pelajaran IPA (fisika) di SMA Negeri 4 lubuklinggau, mengatakan bahwa nilai hasil ulangan harian siswa masih banyak yang memperoleh nilai kurang dari rata-rata atau tidak memenuhi kriteria ketuntasan minimal (KKM) yang ditetapkan yaitu 65. Jumlah siswa sebanyak 130 siswa kelas $X$ di SMA Negeri 4 Lubuklinggau. Hanya 78 orang (60\%) yang mencapai KKM. Sedangkan siswa yang belum tuntas sebanyak 52 orang (40\%) dan harus mengikuti perbaikan atau remedial uutnuk mencapai ketuntasan. Cara guru mengajar menjadi 
penentu keberhasilan proses belajar mengajar. Guru yang mempunyai kemampuan untuk mengajar bisa merasakan dimana saja dia mengajar adalah suatu hal yang menyenangkan. Peran seorang guru harus mampu memberi pengaruh pada muridnya melalui kepribadian. Cara guru mengajar yang baik adalah dengan mengetahui secara jelas obyek pengajaran. Jika pengajaran jelas sasarannya maka akan membuat siswa bisa dengan jelas maksud dari pokok pembelajaran tersebut. Siswa bisa menangkap semua pelajaran, bahkan mereka mengalami kemajuan didalam belajar, dan sebaliknya jika cara guru mengajar baik tetapi belum bisa memotivasi siswa maka akan berpengaruh juga terhadap hasil belajar siswa. Di SMA Negeri 4 Lubuklinggau guru mengajar sudah cukup bagus dengan menggunakan model pembelajaran. Model pembelajaran yang digunakan menyesuaikan dengan materi yang diajarkan. Tetapi guru hanya menggunakan 2 model secara bergantian yang disesuaikan dengan materi yaitu model Inquiry dan Discovery Learning.

Dengan menggunakan kedua model tersebut membuat sebagian siswa lebih aktif dan mandiri, tetapi masih ada siswa yang merasa kesulitan dengan model yang diterapkan dan siswa juga terkadang merasa kurang adanya motivasi yang diberikan oleh guru. Selain itu model yang diterapkan tidak terlalu menuntut guru untuk memaparkan penjelasan tentang materi. Siswa mendapatkan materi atau konsep berdasarkan pratikum atau pengalaman yang dilakukan. hal ini juga yang menyebabkan hasil belajar fisika siswa menjadi rendah.

Solusi untuk mengatasi masalah yang ada perlu menggunakan model pembelajaran yang mengembangkan keterampilan siswa, mendorong siswa lebih aktif berpikir dan berani mengemukakan pendapat dalam proses pembelajaran. Model yang digunakan juga harus sesuai dengan materi yang akan disampaikan agar siswa mudah memahami. Karena model yang digunakan oleh guru akan sangat berpengaruh terhadap cara dan hasil belajar siswa. Salah satu model pembelajaran yang mengajak siswa kedalam situasi baru sehingga siswa bisa lebih aktif berpikir dan bisa mengemukakan pendapat adalah model pembelajaran Probing Prompting.

Menurut Ngalimun (dalam Jatmiko, 2017:165) model pembelajaran Probing Prompting adalah pembelajaran dengan cara guru menyajikan serangkaian pertanyaan yang sifatnya menuntun dan menggali gagasan siswa sehingga terjadi proses berpikir yang mampu 
menghubungkan pengetahuan dan pengalaman siswa dengan pengetahuan baru yang sedang dipelajari, selanjutnya siswa mengkontruksikan konsep, prinsip, dan aturan menjadi pengetahuan terbaru, dengan demikian pengetahuan baru tidak diberitahukan.

Dengan menggunakan model pembelajaran ini diharapkan siswa lebih aktif, lebih termotivasi dan berani mengemukakan pendapatnya dalam proses pembelajaran sehingga tujuan yang diharapkan tercapai. berdasarkan uraian diatas penulis tertarik melakukan penelitian dengan judul" Model Direct Intruction dengan Teknik Probing Prompting : Dampak terhadap Hasil Belajar Fisika kelas X SMA Negeri 4 Lubuklinggau tahun pelajaran 2018/2019”.

\section{LANDASAN TEORI}

\section{a. Belajar}

Belajar adalah kegiatan penting setiap orang, termasuk didalamnya belajar bagaimana seharusnya belajar. Menurut Abdillah (dalam Aunurrahman, 2013:35) menyatakan bahwa belajar adalah suatu usaha sadar yang dilakukan individu dalam perubahan tingkah laku baik melalui latihan dan pengalaman yang menyangkut aspek-aspek kognitif, afekif, dan psikomotor untuk memperoleh tujuan tertentu.

Menurut Gagne (dalam Hardini dan Puspitasari, 2014:4) belajar adalah proses dimana suatu organisme berubah perilakunya akibat dari pengalaman, sedang menurut Skinner (dalam Hardini dan Puspitasari, 2014:4) belajar adalah suatu proses adaptasi atau penyesuaian tingkah laku yang berlangsung secara progresif. Belajar juga dipahami sebagai suatu perilaku, pada saat orang belajar, maka responsnya menjadi lebih baik. sebaliknya, jika ia tidak belajar, responsnya menurun. Dengan demikian berarti diartikan sebagai suatu perubahan dalam kemungkinan atau peluang terjadinya respons.

Berdasarkan pendapat diatas dapat disimpulkan bahwa belajar adalah suatu proses yang dilakukan setiap individu untuk mendapatkan suatu perubahan tingkah laku yang baru secara keseluruhan didalam interaksi dengan lingkungannya, belajar merupakan suatu proses yang mengharuskan adanya perubahan.

\section{b. Hasil Belajar}

Dalam proses belajar mengajar, guru sebagai pengajar sekaligus sebagai pendidik memegang peranan dan tanggung jawab yang besar dalam 
rangka membantu meningkatkan keberhasilan siswa. Keberhasilan siswa dalam proses dalam proses belajar mengajar dipengaruhi oleh kualitas pengajar (guru) dan faktor internal dari siswa itu sendiri. Proses belajar mengajar dilakukan dengan maksud melakukan perubahan dalam diri siswa. Perubahan itu dapat dilihat dari hasil akhir yang diperoleh siswa. hasil akhir ini diidentifikasikan dengan hasil belajar.

Menurut Dimyati dan Mudjiono (dalam Munawaroh dan Alamuddin, 2014:169), “ Hasil belajar merupakan hal yang dapat dipandang dari dua sisi yaitu sisi siswa dan sisi guru. dari sisi siswa, hasil belajar merupakan tingkat perkembangan mental lebih baik bila dibandingkan pada saat sebelum belajar". Tingkat perkembangan mental tersebut terwujud pada jenisjenis ranah kognitif, afektif dan psikomotor. Sedangkan dari sisi guru, hasil belajar merupakan saat terselesaikannya bahan pelajaran". Sedangkan menurut Hamalik (dalam Munawwaroh dan Alamuddin, 2014:169) 'Hasil belajar adalah peruubahan tingkah laku subjek yang meliputi kemampuan kognitif, afektif, dan psikomotor dalam situasi tertentu berkat pengalamannya berulang-ulang.
Berdasarkan teori taksonomi bloom hasil belajar dalam rangka studi dicapai melalui tiga kategori ranah antara lain kognitif, afektif dan psikomotor".

Perinciannya menurut Bloom (dalam Sudjana, 2014:22) adalah sebagai berikut:

a. Ranah kognitif, berkenaan dengan hasil belajar intelektual yang terdiri dari 6 aspek, yakni pengetahuan atau ingatan, pemahaman, aplikasi, analisis, sintesis, dan evaluasi.

b. Ranah afektif, berkenaan dengan sikap yang terdiri dari 5 aspek, yakni penerimaan, jawaban atau reaksi, penilaian, organisasi dan internalisasi.

c. Ranah psikomotor, berkenaan dengan hasil belajar keterampilan dan kemampuan bertindak. ada 6 aspek, yakni gerakan refleks, keterampilan gerakan dasar, kemampuan perseptual, keharmonisan atau ketepatan, gerakan keterampilan komplek, dan gerakan ekspresif dan interpretatif. ketiga ranah tersebut menjadi objek penilaian hasil belajar. diantara ketiga ranah itu, ranah kognitiflah yang paling banyak dinilai oleh para guru disekolah karena berkaitan 
dengan kemapuan para siswa dalam menguasai isi bahan pengajaran.

Hasil belajar adalah kemampuan yang dimiliki setiap individu setelah menerima pengalaman dalam belajarnya. Hasil belajar ini digunakan guru untuk dijadikan ukuran dalam mencapai suatu tujuan pendidikan. Hal ini dapat tercapai apabila proses dari usaha individu untuk memperoleh perubahan perilaku yang relatif tepat.

Menurut Bloom (dalam Jihad dan Haris, 2012:16-17), hasil belajar pada aspek kognitif meliputi :

1) Pengetahuan / Knowledge (C1)

Jenjang yang paling rendah dalam kemampuan kognitif meliputi pengingatan tentang halhal yang bersifat khusus atau universal, mengetahui metode dan proses, pengingatan terhadap suatu pola, struktur atau seting. Dalam hal ini tekanan utama pada pengenalan kembali fakta, prinsip, kata-kata yang dapat dipakai: definisikan, ulang, laporkan, ingatan, garis bawahi, sebutkan, daftar dan sambungkan.

2) Pemahaman / Comprehension (C2)

$\begin{array}{ccr}\text { Jenjang } & \text { setingkat } & \text { diatas } \\ \text { pengetahuan } & \text { ini akan meliputi } \\ \text { penerimaan } & \text { dalam komunikasi }\end{array}$

secara akurat, menempatkan hasil komunikasidalam bentuk penyajian yang berbeda, mengorganisasikannya secara setingkat tanpa merubah pengertian dan dapat mengeksplorasikan. Kata-kata yang dapat dipakai: menterjemah, nyatakan kembali, diskusikan, gambarkan, mengorganisasikan, jelaskan, identifikasi, tempatkan, review, ceritakan, paparkan.

3) Penerapan (C3)

Penggunaan prinsip atau metode pada situasi yang baru. Kata-kata yang dapat dipakai: interprestasikan, menerapkan, melaksanakan, menggunakan, demontrasikan, mempraktekan, mengilustrasikan, mengoperasikan, jadwalkan, sketsa, kerjakan.

4) Analisis (C4)

Jenjang yang keempat ini akan menyangkut terutama kemampuan anak dalam memisah-misah terhadap suatu materi menjadi bagian-bagian yang membentuknya, mendeteksi hubungan diantara bagian-bagian itu dan cara materi itu diorganisir. Kata-kaya yang dapat dipakai : pisahkan, analisa, bedakan, hitung, 
cobakan, test bandingkan kontras,

kririk, teliti, debatkan, inventarisasikan, hubungkan, pecahkan, kategorikan.

\section{5) Sintesa (C5)}

Jenjang yang sudah satu tingkat lebih sulit dari analisa ini adalah meliputi anak untuk menaruhkan/menempatkan

bagian-bagian atau elemen satu/bersama sehingga membentuk suatu keseluruhan yang koheren. Kata-kata yang dapat dipakai: komposisi, ddesain, formulasi, atur, rakit, kumpulkan ciptakan, susun, organisasikan, memanage, siapkan, rancang, sederhanakan.

6) Evaluasi (C6)

Jenjang ini adalah yang paling atas atau yang dianggap paling atas atau yang dianggap paling sulit dalam kemampuan pengetahuan anak didik. Disini akan meliputi kemampuan anak didik dalam pengambilan keputusan atau dalam menyatakan pendapat tentang nilai sesuatu tujuan, idea, pekerjaan, pemecahan masalah, metoda, materi dan lainlain. Dalam pengambilan keputusan atau dalam menyatakan pendapat, termasuk juga kriteria yang dipergunakan, sehingga menjadi akurat dan menstandard penilaian/ penghargaan. Kata-kata yang dapat dipakai : putuskan, hargai, nilai, skala, bandingkan, revisi, skor, perkiraan.

Berdasarkan pengertian diatas maka dapat disimpulkan bahwa hasil belajar adalah suatu penilaian akhir dari proses yang telah dilakukan berulang-ulang. serta akan tersimpan dalam jangka waktu lama atau bahkan tidak akan hilang karena hasil belajar turut serta dalam membentuk pribadi seseorang yang selalu ingin mencapai hasil yang lebih baik lagi sehingga akan merubah cara berpikir serta menghasilkan perilaku kerja yang lebih baik sesuai dengan tujuan yang diinginkan

\section{c. Model Direct Intruction}

Menurut Trianto (dalam Pritandhari, 2017:50) Model Pembelajaran Direct Instruction atau yang dikenal dengan model penganjaran langsung adalah salah satu pendekatan mengajar yang dirancang khusus untuk menunjang proses belajar mengajar peserta didik yang berkaitan dengan pengetahuan deklaratif dan pengetahuan prosedural yang terstruktur dengan baik yang dapat diajarkan dengan pola kegiatan yang bertahap,selangkah demi selangkah. Sedangkan menurut Zahriani $(2014,98)$ model pembelajaran Direct Instruction merupakan model 
pembelajaran yang menekan kan

untuk membuat siswa-siswanya penyampaian materi dilakukan secara membenarkan atau paling tidak verbal oleh guru kepada peserta didik. menjelaskan lebih jauh tentang jawabanBerdasarkan pendapat diatas dapat jawaban mereka dengan cara demikian disimpulkan, bahwa model pembelajaran Direct Instruction merupakan pendekatan mengajar yang dirancang khusus untuk menunjang proses belajar mengajar peserta didik.

d. Langkah-langkah model Direct

Instruction adalah sebagai berikut, dapat dilihat pada tabel 1.1.

Tabel 1.1. Langkah-langkah Model pembelajaran Direct Instruction

\begin{tabular}{|c|c|}
\hline Fase & Peran Guru \\
\hline Fase 1 & Guru $\quad$ menjelaskan \\
\hline Persiapan. & $\begin{array}{llr}\text { pembelajaran } & & \text { dan } \\
\text { mempersiapkan } & \text { siswa } & \text { untuk } \\
\text { belajar. } & & \end{array}$ \\
\hline Fase 2 & Guru mendemonstrasikan \\
\hline $\begin{array}{c}\text { Demontras } \\
\text { i. }\end{array}$ & $\begin{array}{l}\text { keterampilan dengan benar, atau } \\
\text { menyajikan informasi tahap demi } \\
\text { tahap. }\end{array}$ \\
\hline $\begin{array}{c}\text { Fase } 3 \\
\text { Latihan. }\end{array}$ & $\begin{array}{l}\text { Guru merencanakan dan memberi } \\
\text { bimbingan pelatihan awal. }\end{array}$ \\
\hline Fase 4 & Menyimpulkan \\
\hline $\begin{array}{c}\text { Kesimpula } \\
\text { n. }\end{array}$ & $\begin{array}{l}\text { memastikan bahwa siswa benar- } \\
\text { benar memahami materi yang } \\
\text { telah disampaikan. }\end{array}$ \\
\hline
\end{tabular}

\section{e. Teknik Probing Prompting}

Menurut Suherman (dalam Jatmiko, 2017:165) Teknik Probing Prompting ialah pertanyaan yang bersifat menggali untuk mendapatkan jawaban yang lebih lanjut dari siswa yang bermaksud mengembangkan kualitas jawaban, sehingga jawaban berikutnya lebih jelas, akurat serta lebih beralasan. Melalui proses Probing Prompting guru berusaha dapat meningkatkan kedalaman pembahasan. Sedangkan Megariati (dalam Kusuma dan Indrawati, 2015:337) mengatakan 'Teknik Probing Prompting adalah teknik yang cukup efektif dalam upaya meningkatkan hasil belajar dan aktivitas siswa".

\section{f. Langkah-langkah teknik Probing} Prompting dalam penelitian ini adalah :

a. Guru menghadapkan siswa pada situasi baru misalkan dengan persoalan yang menimbulkan permasalahan dengan berupa gambar.

b. Menunggu beberapa saat dan memberikan kesempatan kepada siswa untuk merumuskan jawaban dan melakukan diskusi kecil dalam merumuskan permasalahan.

c. Mengajukan pertanyaan kembali sesuai indikator yang ingin dicapai.

d. Menunggu beberapa saat dan memberikan kesempatan kepada siswa untuk merumuskan jawaban /melakukan diskusi kecil.

e. Meminta perwakilan dari siswa untuk menjawab pertanyaan yang telah diberikan. 
f. Jika jawabannya tepat, guru meminta tanggapan kepada siswa lain tentang jawaban dan jika mengalami kesuilitan dalam menjawab, maka guru mengajukan pertanyaan lain yang menjadi petujuk penyelesaian jawaban.

g. Mengajukan pertanyaan akhir pada siswa lain untuk lebih menegaskan bahwa indikator yang dituju tercapai.

g. Kelebihan dan Kekurangan teknik Probing Prompting

Menurut Shoimin $\quad(2014: 128)$ kelebihan teknik Probing Prompting adalah sebagai berikut :

a. Mendorong siswa lebih aktif berpikir.

b. Memberi kesempatan kepada siswa untuk menanyakan hal-hal yang kurang jelas sehingga guru dapat menjelaskan kembali.

c. Perbedaan pendapat antara siswa dapat dikompromi atau diarahkan.

d. Pertanyaan dapat menaik dan memusatkan perhatian siswa sedang ribut atau ketika sedang mengantuk hilang rasa kantuknya.

e. Sebagai cara meninjau kembali (review) membahas pelajaran yang lampau.

f. Mengembangkan keberanian atau keterampilan siswa dalam menjawab dan mengemukakan pendapat.

g. Pertanyaan dapat menarik dan memusatkan perhatian siswa. h. Kekurangan teknik Probing Prompting menurut Shoimin (2014:129) adalah sebagai berikut:

a. Dalam jumlah siswa yang banyak tidak mungkin cukup waktu untuk memberikan pertanyaan kepada setiap siswa.

b. Siswa merasa takut, apalagi bila guru kurang dapat mendorong siswa untuk berani, dengan menciptakan suasana yang tidak tegang, melainkan akrab.

c. Tidak mudah membuat pertanyaan yang sesuai dengan tingkat berpikir dan mudah dipahami siswa.

d. Waktu sering banyak terbuang apabila siswa tidak dapat menjawab pertanyaan sampai dua atau tiga orang.

e. Dalam jumlah siswa yang banyak, tidak mungkin cukup waktu untuk memberikan pertanyaan kepada setiap siswa.

f. Dapat menghambat cara berpikir anak bila tidak/ kurang pandai membawa diri, misalnya guru meminta siswanya menjawab persis seperti dia kehendaki, kalau tidak dinilai salah.

\section{METODE PENELITIAN}

Metode penelitian adalah cara yang digunakan oleh peneliti dalam mengumpulkan data penelitiannya (Arikunto , 2010:203). Jenis penelitian ini 
adalah penelitian eksperimen semu yang dilaksanakan tanpa ada kelas pembanding. desain penelitian yang digunakan dalam penelitian ini adalah desain One Group Pre-test Post-test. Adapun pola menurut (Arikunto 2010:124) dapat dilihat pada tabel 1.

Tabel 1. Desain One Group Pre-test Post-test

\begin{tabular}{lll}
\hline 01 & $X$ & 02 \\
\hline
\end{tabular}

Keterangan :

$\mathrm{O} 1=$ Tes yang dilakukan sebelum eksperimen( Pretest)

$\mathrm{O} 2=$ Tes yang dilakukan sesudah eksperimen( Post-test)

$\mathrm{X}=$ Pengajaran dengan menggunakan model Direct Instruction dengan teknik Probing Prompting

\section{HASIL DAN PEMBAHASAN}

1) Data Tes

a. Hasil Kemampuan Awal siswa (Pre-test)

Kemampuan pre-test adalah kemampuan yang terlihat dari kesiapan diri siswa dalam menerima pembelajaran yang akan berikan oleh guru. Rekapitulasi data hasil tes awal dapat dilihat pada tabel 2 .

Tabel 2.Rekapitulasi DataTes Awal ( Pre-test)

\begin{tabular}{cc}
\hline Kategori & Hasil \\
\hline Rata-rata nilai & 44,13 \\
Simpangan baku & 12,28 \\
Nilai tertinggi & 66 \\
Nilai terendah & 25 \\
Siswa Yang tuntas & $2(5,55 \%)$ \\
Siswa yang belum tuntas & $34(94,45 \%)$
\end{tabular}

Berdasarkan tabel 4.1 diatas dapat dilihat bahwa $2(5,55 \%)$ siswa yang mendapat nilai lebih atau sama dengan KKM yaitu 65. dan rata-rata nilai keseluruhan sebesar 44,13. jadi secara deskriptif dapat dikatakan bahwa kemampuan awal siswa sebelum penerapan model Direct Instruction dengan teknik Probing Prompting termasuk kategori belum tuntas.

\section{b. Hasil Kemampuan akhir siswa (Post- test)}

Kemampuan akhir siswa bertujuan untuk mengetahui penguasaan materi vektor dan bertujuan untuk mengetahui kemampuan akhir siswa setelah mengikuti proses belajar mengajar. Kemampuan hasil akhir diperoleh dengan melalui tes akhir yaitu Post-test. Pelaksanaan Posttest dilakukan setelah diberikan perlakuan pada proses pembelajaran menggunakan model Direct Instruction dengan teknik Probing Prompting . 
Tabel 3. Rekapitulasi DataTes Akhir ( Post-test)

\begin{tabular}{cc}
\hline Kategori & Hasil \\
\hline Rata-rata nilai & 75,11 \\
Simpangan baku & 14,36 \\
Nilai tertinggi & 93 \\
Nilai terendah & 41 \\
Siswa Yang tuntas & $29(80,5 \%)$ \\
Siswa yang belum & $7(19,5 \%)$ \\
tuntas & \\
\hline
\end{tabular}

Berdasarkan tabel 3 diatas dapat dilihat bahwa siswa yang mendapat nilai lebih atau sama dengan KKM yaitu 65 sebanyak 29 siswa $(80,5 \%)$. dan rata-rata nilai keseluruhan sebesar 75,11. jadi secara deskriptif dapat dikatakan bahwa kemampuan akhir siswa setelah penerapan model Direct Instruction dengan teknik Probing Prompting termasuk kategori tuntas. Jadi dapat disimpulkan bahwa nilai rata-rata posttest mengalami peningkatan sebesar 30,98 dan ketuntasan hasil belajar siswa mengalami peningkatan sebesar $(80,5 \%)$. untuk lebih jelasnya dapat dilihat pada grafik 1.

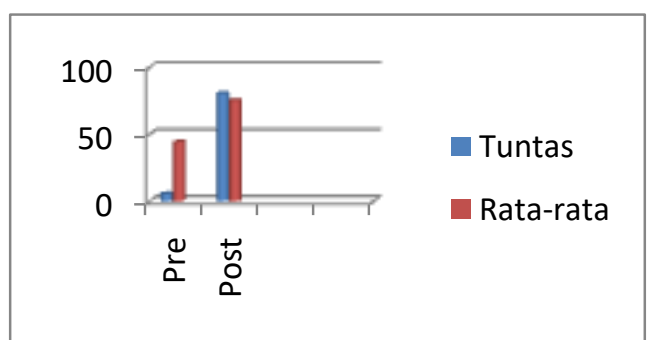

Grafik 1. Nilai Rata-rata dan Ketuntasan Hasil Belajar

\section{PEMBAHASAN}

Penelitian ini termasuk jenis penelitian kuantitatif dengan metode eksperimen yang dilaksanakan di SMA Negeri 4
Lubuklinggau dengan materi vektor dengan diberi perlakuan model Direct Instruction dengan teknik Probing Prompting. Penelitian ini dapat berangkat dari adanya potensi atau masalah. Masalah yang ditemui pada saat observasi adalah masih banyaknya nilai siswa yang belum mencapai kriteria ketuntasan minimal (KKM). Karena pada saat proses pembelajaran siswa tidak terlibat secara langsung sehingga pembelajaran menjadi menoton. Dengan adanya masalah ini peneliti ingin memberikan perlakuan dengan menggunakan model Direct Instruction disertai teknik Probing Prompting dikelas X SMA Negeri 4 Lubuklinggau. Teknik ini merupakan teknik yang inovatif, dimana siswa diberi kesempatan untuk berani, dan lebih aktif serta terlibat langsung didalam proses pembelajaran dalam menyelesaikan sebuah permasalahan yang diberikan oleh guru.

Tujuan dari dilakukannya penelitian ini adalah untuk meningkatkan hasil belajar siswa. Menurut Sudjana (dalam Alamuddin dan Munawwaroh, 2014:169) hasil belajar merupakan kemampuan yang dimiliki siswa setelah menerima pengalaman belajar. penelitian ini dilakukan dengan tahap uji instrument soal, Pre-test, Perlakuan sebanyak 2 kali, dan Post-test. Penelitian dilaksanakan 
mulai dari tanggal 17 September 2018 sampai tanggal 30 Oktober 2018.

Didalam penelitian ini hasil belajar pada kelas eksperimen tinggi disebabkan oleh beberapa keunggulan dari teknik Probing Prompting. Dari penggunaan teknik Probing Prompting proses pembelajaran dilakukan dengan cara guru menghadapkan siswa pada situasi baru, misalkan dengan memberikan gambar mengandung permasalahan kemudian guru memberi kesempatan kepada siswa untuk merumuskan jawaban dan menunujuk salah satu siswa untuk menjawab pertanyaan. Jika jawabanya tepat maka guru meminta tanggapan dari siswa untuk meyakinkan bahwa seluruh siswa terlibat dalam kegiatan yang berlangsung, jika jawabannya kurang tepat atau siswa tersebut diam maka guru memberikan pertanyaan lain yang jawabannya merupakan petunjuk jalan penyelesaian masalah.

Kemudian di akhir pembelajaran guru memberi pertanyaan yang berbeda untuk melihat bahwa indikator benar-benar dipahami oleh seluruh siswa. Pembelajaran dengan menggunakan teknik Probing Prompting merupakan salah satu cara agar siswa lebih aktif dalam proses pembelajaran yang sedang berlangsung, karena dalam pembelajaran ini siswa tidak merasa terbebani oleh materi. dalam pembelajaran ini siswa mengamati terhadap situasi baru sehingga terjadinya proses berpikir dan mengembangkan keberanian siswa dalam menjawab dan mengemukakan pendapatnya.

Dilihat dari ketuntasan hasil belajar fisika siswa di SMA Negeri 4 Lubuklinggau dengan KKM yang ditetapkan 65 untuk pelajaran fisika. Pada kelas ekperimen dari jumlah siswa 36 jumlah siswa 29 siswa $(80,5 \%)$ yang sudah tuntas atau mencapai kriteria ketuntasan minimum (KKM). Sedangkan 7 siswa yang belum mencapai kriteria ketuntasan minimum (KKM).

\section{SIMPULAN DAN SARAN}

\section{a. SIMPULAN}

Berdasarkan hasil penelitian yang sudah dilakukan bahwa hasil belajar siswa kelas X SMA Negeri 4 Lubuklinggau setelah diterapkan model Direct Instruction dengan teknik Probing Prompting secara signifikan tuntas. Nilai rata-rata hasil belajar sebesar 75,11 dan presentase jumlah siswa yang tuntas mencapai $80,5 \%$.

\section{b. SARAN}

Sehubungan dengan hasil penelitian yang ingin dituju pada penelitian yang dilakukan di SMA Negeri 4 
Lubuklinggau, maka penulis memberikan saran :

1. Guru sebaiknya lebih memvariasikan pada saat proses pembelajaran, salah satu model atau strategi yang digunakan untuk membuat siswa lebih tertarik dalam belajar adalah dengan menampilkan gambar (teknik Probing Prompting).

2. Guru harus memahami langkahlangkah atau tahapan pelaksanaaan teknik pembelajaran, jika tidak justru akan mengacaukan proses pembelajaran yang berlangsung.

3. Teknik Probing Prompting ini sama seperti halnya dengan teknik / model pembelajaran yang lainnya yang tidak bisa diterapkan disemua bahan ajar.

4. Dengan menggunakan teknik Probing Prompting ini siswa dituntut dapat berani mengemukakan pendapatnya .

5. Peneliti, mendapatkan wawasan serta pengalaman baru selama proses pembelajaran dikelas yang menggunakan teknik Probing Prompting.

\section{DAFTAR PUSTAKA}

Arikunto. 2010. Prosedur Penelitian Suatu Pendekatan Praktik. Jakarta: Rineka Cipta.

Aunurrahman. 2012. Belajar dan Pembelajaran.

Bandung:Alfabeta.
Bloom. 2014. Penilaian Hasil Belajar Mengajar. Bandung: PT Rineka Rosdakarya.

Hardini dan Puspita. 2014. Strategi Pembelajaran Terpadu ( Teori, Konsep dan Implementasi). Yogyakarta: Familia (Group Relasi Inti Media).

Jihad dan Haris. 2012. Evaluasi Pembelajaran.Yogyakarta:

Multi Pressindo.

Jatmiko. 2017. Perbedaan Pengaruh Model Pembelajaran Probing Prompting dan SQ4R Siswa Madrasah Aliyah. Jurnal Gammah, vol 2 No, Hal:165.

Kusuma dan Indrawati. 2015. Model Pembelajaran Learning disertai Teknik Probing Prompting dalam Pembelajaran Fisika di MA. Jurnal Pendidikan Fisika, vol 3 No 4, Hal:337.

Munawaroh dan Alamuddin. 2014. Pengaruh Penerapan Model Pembelajaran Snowball Throwing terhadap Hasil Belajar Matematika Siswa dengan Pokok Bahasan Rotasi dan Fungsi. EduMavol 3 No 2.

Pritandhari, Meyta. 2017. Implementasi Model Pembelajaran Direct Instruction Untuk Meningkatkan Kemampuan Berpikir Kreatif Mahasiswa. Jurnal Pendidikan Ekonomi UM Metro. vol 5. No 1. Hal : 47-56

Sudjana. Nana, 2016. Penilaian Hasil Proses Belajar Mengajar. Bandung : PT Remaja Rosdakarya.

Shoimin. 2014. 68 Model Pembelajaran Inovatif dalam Kurikulum 2013. Maguhuharjo: AR-RUZZ MEDIA. 
Suyono dan Hariyanto. 2012. Belajar dan Pembelajaran (Teori dan Konsep Dasar). Bandung : PT Remaja Rokdakarya.

Zahriani, 2014. Kontektualisasi Direct Instruction Dalam Pembelajaran Sains. Lantanida Jurnal. vol.1 No.1. 